\title{
Continuous Use Intention of Corporate Mobile SNS Users and its Determinants: Application of Extended Technology Acceptance Model
}

\author{
Joon-Hee Kim ${ }^{1}$, Myeong-Suk Kim ${ }^{2}$, Ryung-Kee Hong ${ }^{3}$, Jong-Wook Ko ${ }^{4}$ \\ ${ }^{1}$ Adjunct Professor, Hoseo Univ., 212-1103, 346-2, Sangdo-ro, Dongjak-gu, Seoul, \\ Korea \\ 2 Joystone Co., 15 Mapodae-ro, Mapo-gu, Seoul, Korea \\ ${ }^{3}$ Aju Pharm, 71-2 Jinheung-ro, Unpyung-gu, Seoul, Korea \\ ${ }^{4}$ Dept. Public Administration, Anyang Univ., 37-22 Samdek-ro, Manan-gu, Anyang, \\ Gyeonggi-do, Korea \\ perideau@naver.com,jarakim65@naver.com,rkhong@ajupharm.co.kr,jwko@anyang.ac.kr
}

\begin{abstract}
This study was intended to investigate the continuous use intention of corporate mobile SNS users and its determinants on the basis of extended technology acceptance model. For this purpose, this study examined user and social characteristics as independent variables and perceived ease of use and perceived availability as mediating variables. The sample of this study was composed of 332 cooperate mobile SNS users collected through structured questionnaires and analyzed using SEM technique. This study found that four user and social characteristics of variables impact positively on the two mediating variables and that the two mediating variables have positive effects on continuous use intention. Theoretical and practical implications of these findings were discussed and the policy proposals were suggested.
\end{abstract}

Keywords: corporate mobile SNS, user characteristics, social characteristics, continuous use intention.

\section{Introduction}

The global smartphone market is leading high growth despite the global economic downturn. The latest mobile communication technology is developing into the $5 \mathrm{G}$ (5th generation) era beyond 3G (3rd generation) and 4G (4th generation). The development of the wireless Internet and the increase of use in the penetration rate of smartphones are creating a new environment in the information age as a driving 
force to create and develop an Internet-based industry. In addition, the media environment to come up as a great power in the information age, is a technical media environment necessary for communication between organizations and individuals, organizations and organizations, as well as individuals and individuals.

The expansion of SNS enables the free communication between consumers online as the network expands, and is being used as a communication tool that can exchange opinions on each individual's common interest, as well as provides various and useful information and enables social relations which transcends time and space. Moreover, the corporate and consumer relationships are transforming from passive to active (Bryant, 2006). In other words, SNS is not merely for maintaining the relationship but used as a tool for exploring and reproducing information through sharing, depending on the use motives. The utilization of SNS is increasing day by day-from tools for communicating with close people, into forming relationships with strangers, obtaining information, and delivering personal and local news.

According to the '2018 Internet Usage Survey', the Internet usage rate has steadily increase to $91.5 \%$, the increase of use of $1.2 \%$ from the previous year, and $65.2 \%$ for SNS usage and $65.0 \%$ for mobile device usage among the internet user (Internet use survey, 2018). The usage of main SNS service resulted to 'Facebook' (65.7\%), 'Kakao Story' (49.6\%), and 'Instagram' (41.0\%). Among the Internet users, $75.8 \%$ do information acquisition activity such as information gathering from SNS. As such, unlike existing mass media, the characteristic of availability on information sharing and communication between information providers and receivers and between audiences and audiences, has attracted much attention as a new marketing channel in various fields of society (Lim, et al., 2017). In addition, companies can use it as an important channel in charge of Customer Relationship Management, from the basic service such as launching new products or delivering fresh corporate news report to the company. In order to do this, they operate a dedicated department directly or conduct marketing through a social media marketing company.

However, in the case of corporate SNS in the mobile environment, it is unable to cope with the recent changes in the aspect of delivering one-sided information or program rather than aiming for user communication and active participation. The introduction of the new information system can only be expected when the system is properly used for the consumer, and securing competitiveness through corporate mobile can only be achieved on the condition of consumer's acceptance and widespread use. For this reason, the use of information technology is considered as a major dependent variable and its importance has been emphasized in many management information system studies (DeLone, 1992), and the technology acceptance model is used as an optimal model to explain user acceptance and usage behavior. 
Therefore, the technology acceptance model (TAM) is one of the representative theories that have been applied to various researches not only for the initial use of the information system but also to be able to form the continuous use intention. Many preceding researches agreed that the two belief variables (perceived ease of use and availability) perceived by users of ease of use are valid concepts for predicting the acceptance of information systems, and this model was supported by many empirical studies because of its concise and powerful nature that explains the acceptance and spread of information technology (Davis, 1986; Davis et al., 1989; Dishaw, 1999; Mathieson, 1991; Venkatesh, 1996). However, as technology has advanced, existing technology acceptance models had imitations and follow-up studies have been conducted in various fields to identify various preceding variables that affect perceived availability and ease of use (Davis et al., 1992; Han et al., 2010) and DeLone \& McLean's (2003) Extended TAM (ETAM) has been proposed, which emphasizes the importance of service and information quality (Delone, 2003). In the ETAM. studies using system characteristic factors as external variables have been dominant (Venkatesh, 2000), but few studies have dealt with them, although user characteristics and social characteristic factors are important as characteristics of SNS (Cho, 2012)

Therefore, this study proposes an extended technology acceptance model theory through additional variables based on the existing technology acceptance model, to identify structural relationship between user characteristics factors (personal innovativeness, personal familiarity) and social characteristics factors (social influence, social interaction). It will help determine the continuous use intention through perceived availability and ease of use provide a theoretical basis for corporate mobile SNS by analyzing the causal relationship between factors, and provide practical implications that can help the company's effective use and marketing strategy.

\section{Theoretical Background of Research}

The main interest of this study is to explore the determinants of continuous use intention, to which indicates the willingness to continue using the company's mobile SNS. Recent studies in the areas of marketing and management information show that the success of a product or service is not the first use for consumers, but the continued use depends on the success of the company (Delone, 2003). Companies are paying attention to corporate mobile SNS that applies the technology acceptance model in order to keep consumers using their products or services. The technology acceptance model is developed to explain and predict the behavior of users who use various information technologies whenever high-tech products and new IT-related products are put on the market (Venkatesh, 2000).

The technology acceptance model is based on rational behavior and planned behavior theory (Davis, 1986). Theory of Reasoned Action (TRA) means a person's 
action is influenced by the behavioral intention when one actually takes, which is determined by the attitude toward the behavior and the subjective norms associated with the behavior (Fishbein, 1975). However, this theory has the limitation of not being able to objectify abstract concepts such as individual standards, beliefs, and evaluations, etc. In order to overcome these limitations, Ajzen (1985) proposed a planned behavioral theory by adding the variable as user's perceived behavioral control to the rational behavioral theory (Ajzen, 1985). This theory considers that external variables such as design characteristics, user characteristics, task characteristics, process characteristics, organizational structure, etc. of information technology systems, etc. affect user's acceptance intention according to individual attitudes and moral standards. However, this theory also has the disadvantage that external factors affect seriously on facilitating and controlling the adoption of technology, but do not provide a subset to measure each factor in detail. Accordingly, Davis (1986) suggested a technology acceptance model that and embodies the determinants of attitude toward behavior with the concept of perceived availability and perceived ease of use of use in order to explain the determinants of acceptance of information technology and to present the theoretical justification (Choi, 2012). Two variables - perceived usefulness and perceived ease of use as two important beliefs in user acceptance are the heart of this model.

Since the late 1990s, as belief variables in technology acceptance model is too simple, and that the limitation of being measured as a single item is perceived, extended studies by revising model or introducing various factors have been proposed (Venkatesh, 2000; Choi, 2012). And Davis et al. (1992), and Shen et al. (2015) suggested the technology acceptance model that perceived availability and perceived ease of use effect directly on behavioral intention, except for attitude variables (Davis, 1992; Shen et al., 2015). Also, this model suggested factors that can affect perceived availability social influences or work-relatedness and cognitive tools such as image and quality, and factors that can affect perceived ease of use are self-efficacy and anxiety about technology, curiosity, interest and pleasure. Venkatesh (2008), on the other hand, modified the basic technology acceptance model and suggested the technology acceptance model 3 that external variables such as individual differences, system characteristics, social influence, and promotion conditions affect the behavioral intention and use behavior through perceived availability and perceived ease of use (Venkatesh, 2008). This study aims to explore the determinants of continuous use intention based on the extended technology acceptance model. In this regard, user and social characteristics factors as external variables are reviewed, and two variables as perceived ease of use and perceived availability is set to be a parameter.

First of all, this study examines user characteristics and social characteristics factors as external variables to determine continuous use intention based on the extended technology acceptance model. Growth of mobile networks and expansion 
of mobile SNS, as developing into the information technology used by individual users, are selected by voluntary decisions based on personal beliefs and connected to continuous use according to personal characteristics end users who use information technology which play an important role in embracing new technologies (Agarwal, 2000; Venkatesh, 2000). This study explores two variablespersonal innovativeness and personal familiarity as user characteristic variables. Personal innovativeness refers to the individual's willingness or voluntarily behavior to try a new information technology or voluntary, while personal familiarity refers to the degree of familiarity with using mobile SNS services as a personal judgment of the company's ability to use mobile SNS.

SNS, one of the new information technologies, is a service that supports to move the concept of off-line social relations into on-line, its social characteristics are very important because it focuses on the satisfaction of social relation-oriented motivations rather than other content-oriented websites (Kim, 2011; Kim et al., 2018). Social characteristics include social influences and social interactions. Social influence refers to the degree of influence from others or society in social relations at the time of using the corporate mobile SNS service, while social interaction refers to the degree of recognition on the formation of mutual relationship and share on information and knowledge between corporate mobile SNS and users.

This study explores he two variables of perceived ease of use and perceived availability as parameters based on the extended technology acceptance model. Perceived ease of use is the degree of subjective belief that an information system user can use a particular information system without much effort, and indicates the degree to which the process of learning or using the information system will be relatively easy (Davis, 1986). The perception that any technology is easy to use plays a catalytic role that directly increases the possibility of information technology acceptance. On the other hand, a technology in the same environment is easy to use indirectly makes the technology feel useful, which ultimately increase the willingness to accept information technology. In this study, perceived ease of use refers to the degree of perception that users can use the corporate mobile SNS conveniently and easily.

Perceived availability is the degree of subjective belief that the system uses after using the information system that can improve the individual's productivity. It also means the degree of belief in work efficiency and the improvement of efficiency related to productivity (Davis, 1989; Jiang et al., 2015). In other words, perceived usefulness is the degree of feeling that it is better for work or life to accept technology than not. In this study, perceived usefulness refers to the degree of recognition as efficient and high value in using corporate mobile SNS.

In the relevant empirical studies inside and outside of the country, Agarwql (2000) and Kishore (2001) found that the user's characteristic variables of personal innovativeness and personal familiarity have a positive effect on the continuous use 
intention through the perceived ease of use and availability as parameters (Agarwal, 2000; Kishore et al., 2001). Geum's research (2014) which explored the effect of corporate SNS characteristics on the sustained use intention, also showed that the user characteristics variables had positive effects on the perceived ease of use and availability and the sustained use invention. Rho (2007) reported the same results in a study on the effect of mobile characteristics on mobile service acceptance (Keum et al., 2014; Noh, 2007).

Verkasalo et al. (2010) and Venkatesh (2000) found, on the other hand, in the study for mobile service acceptance that social influence and social interaction variables as social characteristics variables had positive effects on continuous use intention through the perceived availability and perceived ease of use as parameters (Venkatesh, 2000; Verkasalo et al., 2010). Similarly, in Cho's research (2012) on the adoption of social network services, social characteristic variables were found to affect behavioral intentions ultimately through perceived availability and ease of use (Cho, 2012). Kim (2012) and Xin (2018) reported the same results for the characteristics factor of corporate mobile social network service (MSNS) in the study on user satisfaction and continuous use intention (Kim et al., 2012; Xin, 2018).

Regarding the relationship between the perceived ease of use and perceived availability, Kishore et al. (2001) and Verkasalo et al. (2010) found that perceived ease of use have positive effects on perceived usability in the mobile acceptance intention study (Kishore et al., 2001; Verkasalo et al., 2010), and Kim et al. (2012) also found that the perceived ease of use affects the perceived availability in the continuous use intention study for corporate mobile SNS.

In the light of theories and empirical studies reviewed above, user characteristic variables (personal innovativeness, personal familiarity) and social characteristic variables (social influence, social interaction) have positive effects on perceived ease of use and perceived availability as parameters and the perceived availability and perceived ease of use as parameters are expected to have positive effects on the continuous use intention as a dependent variable. In addition, with regard to the relationship between the perceived ease of use and the perceived availability, the perceived ease of use is expected to have positive effects on the perceived availability. Aggregating all to show as a model, the research model is the same presented in Figure 1 as below. 


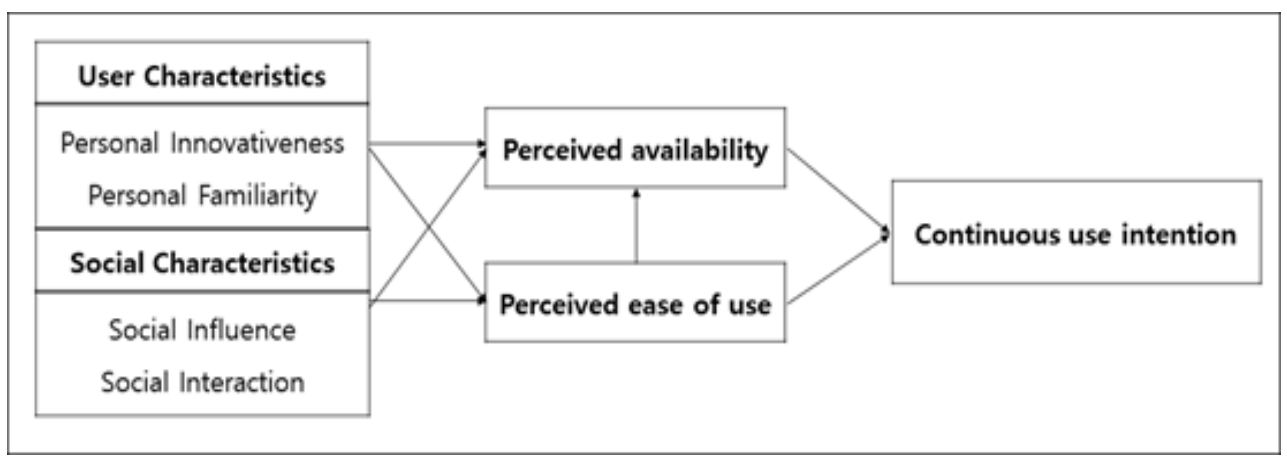

Fig. 1: Study model

\section{Study Method}

\subsection{Data collection and characteristics of the sample}

The data for this study were collected from office workers with experience in using corporate mobile SNS. A standardized questionnaire was used as a data collection tool. The data was collected by using self-administered questionnaire after visiting 9 companies who had indicated their willingness to cooperate in this study and selecting 400 employees randomly among the employees who have experience using corporate SNS in each company. Data were collected for about 15 days from February 6 to February 20, 2018 and 332 copies out of 400 questionnaires were used for data analysis, except for 68 copies with poor responses.

After reviewing the demographic characteristics of the samples used in the analysis, the gender rate showed $50.3 \%$ for males and $49.7 \%$ for females, $43.1 \%$ for $20 \mathrm{~s}, 47.6 \%$ for $30 \mathrm{~s}$, and $9.3 \%$ for over $40 \mathrm{~s}$, and there was a distribution on education such as $5.7 \%$ high school graduates, $11.4 \%$ college graduates, $72.0 \%$ university graduates, and $10.8 \%$ graduate or over. The annual income is $7.2 \%$ for less than 20 million won, $24.7 \%$ for 20 to 30 million won, $25.3 \%$ for 30 to 40 million won, $13.9 \%$ for 40 to 50 million won, and before $28.9 \%$ for more than 50 million won. The time to use SNS is $50.3 \%$ for less than 1 hour, $30.7 \%$ for 1 to 2 hours, $12.3 \%$ for 2 to 4 hours, and $6.6 \%$ for more than 4 hours, and the SNS use time is $18.3 \%$ for less than 1 month, $19.0 \%$ for 2 to 3 months, $12.3 \%$ for $4-5$ months, $6.3 \%$ for 6 months, and $44.0 \%$ for 6 months or more.

\subsection{Measuring variables}

In this study, the personal innovativeness was measured by selecting 5 items from the scale developed by Agarwal (2000) among the user characteristics variables as an independent variable and the personal familiarity was measured by selecting 4 items were selected and measured from the scale developed by Buellingen (Buelingen, 2004). In addition, social influence among social characteristic 
variables was measured by selecting 4 items from the scale developed by Rogers (2003) and social interaction was measured by 4 items from the scale developed by Venkatesh et al. (2002) (Rogers, 2003; Venkatesh et al., 2003). The perceived ease of use was measured by selecting 5 items from the scale developed by Davis (1989), and the perceived availability was measured by selecting 5 items from the scale developed by Davis himself (Davis, 1989). Continuous use intention as a dependent variable was measured by selecting 4 items from the scale developed by Thong et al. (2006). The responses to the questions used in the measurement of all theoretical variables, except for demographic variables, were made using a Likert 5-point scale with five response categories ranging from 'yes' to 'never'.

\subsection{Data analysis method}

As it is unnecessary, Frequency analysis was conducted to identify the characteristics of the sample, and factor analysis and reliability analysis using Cronbach's alpha coefficient were performed to estimate the validity and reliability of the measurement tool. In addition, correlation analysis was conducted to identify the relationships among the variables included in the analysis. The structural equation model technique is applied to analyze the research model presented above.

\section{Analysis Result}

\subsection{Analysis results for validity and reliability}

Confirmatory factor analysis was performed using AMOS 22.0 to determine whether the scale used to measure the variables had adequate validity. The results are presented in Table 1. In general, if the model fitness index is above .90 or the RMR is below .05, the model fit is judged to be excellent (Nunnally, 1978; Kim, 2001; Bagozzi, 1988). In this study, the model fit index of the measurement model used for factor analysis showed that the IFI is .935 , the TLI is .924 , and the CFI is .934 , all of which are above .90 and the model fit is excellent because RMR is .030, which is smaller than .05. In addition, the factor loading of each measurement item showed that all of them were properly loaded with the corresponding factors, at least .70 .

In the confirmatory factor analysis, if average variance extracted (AVE) is above .50 and the concept reliability (CR) is above .70 , it is considered to have proper convergence validity. In addition, if the square root of the AVE of each component is larger than the correlation between the other components, it is judged to have appropriate discriminant validity (Fornell, 1981; Hair et al., 2006). Table 1 shows that all AVE and CR values are above .60 and above .70, respectively. In addition, Table 2 shows that the square root of AVE of each component is larger than the correlation between the other components. Therefore, it is found that the scales used to measure variables in this study have appropriate convergence and 
discriminant validity.

In general, if the reliability coefficient of the scale is more than .80 , it is judged as a very satisfactory level. The Cronbach's alpha values in the first column on the right of Table 1 show that individual innovation is .859 , personal familiarity is .832 , social impact is .817 , and social interaction is .840 , perceived ease of use is .838 , perceived usefulness is .805 , and continuous use intention is .842 , exceeding .80 . Therefore, it is found that the measures used in this study have a very satisfactory level of reliability

Table 1: CFA and reliability analysis results

\begin{tabular}{|c|c|c|c|c|c|c|}
\hline Factor & Question & $\begin{array}{l}\text { Factor } \\
\text { Loading }\end{array}$ & Error & AVE & CR & $\alpha$ \\
\hline \multirow{5}{*}{$\begin{array}{l}\text { Personal } \\
\text { Innovativeness }\end{array}$} & $\begin{array}{l}\text { I try new information technology } \\
\text { of corporate mobile SNS before } \\
\text { others. }\end{array}$ & .770 & .276 & \multirow{5}{*}{.662} & \multirow{5}{*}{.907} & \multirow{5}{*}{.859} \\
\hline & $\begin{array}{l}\text { I like to use a new way of } \\
\text { corporate mobile SNS. }\end{array}$ & .717 & .267 & & & \\
\hline & $\begin{array}{l}\text { I do not hesitate to use corporate } \\
\text { mobile SNS. }\end{array}$ & .747 & .241 & & & \\
\hline & $\begin{array}{l}\text { I am more friendly than others } \\
\text { using corporate mobile SNS. }\end{array}$ & .758 & .276 & & & \\
\hline & $\begin{array}{l}\text { I know more about how to use } \\
\text { corporate mobile SNS. }\end{array}$ & .718 & .346 & & & \\
\hline \multirow{3}{*}{$\begin{array}{l}\text { Personal } \\
\text { Familiarity }\end{array}$} & $\begin{array}{l}\text { I'm used to finding the services I } \\
\text { need for corporate mobile SNS. }\end{array}$ & .823 & .145 & \multirow{3}{*}{.774} & \multirow{3}{*}{.911} & \multirow{3}{*}{.832} \\
\hline & $\begin{array}{l}\text { I'm used to using corporate mobile } \\
\text { SNS to get the services I need. }\end{array}$ & .710 & .271 & & & \\
\hline & $\begin{array}{l}\text { I find the use of corporate mobile } \\
\text { SNS very natural. }\end{array}$ & .855 & .141 & & & \\
\hline \multirow{4}{*}{$\begin{array}{l}\text { Social } \\
\text { Influence }\end{array}$} & $\begin{array}{l}\text { Most of the important people } \\
\text { related to me use corporate mobile } \\
\text { SNS. }\end{array}$ & .724 & .284 & \multirow{4}{*}{.660} & \multirow{4}{*}{.885} & \multirow{4}{*}{.817} \\
\hline & $\begin{array}{l}\text { I want to differentiate myself from } \\
\text { others by utilizing the new } \\
\text { corporate mobile SNS. }\end{array}$ & .778 & .252 & & & \\
\hline & $\begin{array}{l}\text { I use a new corporate mobile SNS } \\
\text { to keep up with fashion. }\end{array}$ & .800 & .280 & & & \\
\hline & $\begin{array}{l}\text { The use of corporate mobile SNS } \\
\text { service gives a good image to } \\
\text { others. }\end{array}$ & .727 & .365 & & & \\
\hline \multirow{4}{*}{$\begin{array}{l}\text { Social } \\
\text { Interaction }\end{array}$} & $\begin{array}{l}\text { Corporate Mobile SNS can make } \\
\text { friends with each other. }\end{array}$ & .791 & .213 & \multirow{4}{*}{.717} & \multirow{4}{*}{.910} & \multirow{4}{*}{.840} \\
\hline & $\begin{array}{l}\text { Corporate Mobile SNS can easily } \\
\text { exchange opinions among its } \\
\text { members. }\end{array}$ & .798 & .234 & & & \\
\hline & $\begin{array}{l}\text { I share corporate mobile SNS } \\
\text { better through collaboration and } \\
\text { participation with other users. }\end{array}$ & .756 & .263 & & & \\
\hline & $\begin{array}{l}\text { I share my knowledge and } \\
\text { information with other users in the } \\
\text { corporate mobile SNS. }\end{array}$ & .778 & .249 & & & \\
\hline
\end{tabular}




\begin{tabular}{|c|c|c|c|c|c|c|}
\hline \multirow{4}{*}{$\begin{array}{l}\text { Perceived } \\
\text { Ease of use }\end{array}$} & $\begin{array}{l}\text { Corporate Mobile SNS is easy and } \\
\text { simple to use overall. }\end{array}$ & .773 & .241 & \multirow{4}{*}{.708} & \multirow{4}{*}{.907} & \multirow{4}{*}{.838} \\
\hline & $\begin{array}{l}\text { You can quickly learn how to use } \\
\text { corporate mobile SNS. }\end{array}$ & .738 & .224 & & & \\
\hline & $\begin{array}{l}\text { Enterprise mobile SNS can easily } \\
\text { find and share the desired } \\
\text { information. }\end{array}$ & .763 & .223 & & & \\
\hline & $\begin{array}{l}\text { You can easily explain to others } \\
\text { how to use corporate mobile SNS. }\end{array}$ & .733 & .243 & & & \\
\hline \multirow{4}{*}{$\begin{array}{l}\text { Perceived } \\
\text { Availability }\end{array}$} & $\begin{array}{l}\text { Corporate mobile SNS is useful in } \\
\text { my daily life. }\end{array}$ & .777 & .196 & \multirow{4}{*}{.706} & \multirow{4}{*}{.906} & \multirow{4}{*}{.805} \\
\hline & $\begin{array}{l}\text { Corporate mobile SNS provides } \\
\text { me convenience. }\end{array}$ & .719 & .238 & & & \\
\hline & $\begin{array}{l}\text { Corporate mobile SNS effectively } \\
\text { provides the information I want. }\end{array}$ & .722 & .247 & & & \\
\hline & $\begin{array}{l}\text { The use of corporate mobile SNS } \\
\text { is more useful than using other } \\
\text { means (TV, advertising, etc.). }\end{array}$ & .754 & .238 & & & \\
\hline \multirow{4}{*}{$\begin{array}{l}\text { Continuous } \\
\text { Use Intention }\end{array}$} & $\begin{array}{l}\text { I will continue to use corporate } \\
\text { mobile SNS without interruption. }\end{array}$ & .741 & .213 & \multirow{4}{*}{.714} & \multirow{4}{*}{.914} & \multirow{4}{*}{.842} \\
\hline & $\begin{array}{l}\text { I have a will to use corporate } \\
\text { mobile SNS by increasing the } \\
\text { frequency of use in the future. }\end{array}$ & .731 & .256 & & & \\
\hline & $\begin{array}{l}\text { Under the same conditions, } \\
\text { corporate mobile SNS will be } \\
\text { used. }\end{array}$ & .784 & .192 & & & \\
\hline & $\begin{array}{l}\text { We will continue to use corporate } \\
\text { mobile SNS at the current level } \\
\text { (time and frequency). }\end{array}$ & .772 & .203 & & & \\
\hline \multicolumn{7}{|c|}{$\chi^{2}=664.292, \mathrm{df}=329, \mathrm{P}=.000, \mathrm{IFI}=.935, \mathrm{TLI}=.924, \mathrm{CFI}=.934, \mathrm{RMR}=.030$} \\
\hline
\end{tabular}

\subsection{Analysis results for validity and reliability}

The results of analyzing the correlations among the variables included in this study are presented in Table 2. Table 2 shows that the innovativeness and familiarity of personal user factors, social influence and social interaction, which are user characteristics, have a significant positive relationship with the perceived ease of use and perceived availability as parameters and the perceived ease of use significantly correlated with perceived availability. In addition, both variables of perceived ease of use and perceived availability, which are parameters, were found to have a significant positive relationship with continuous use intention, which is a dependent variable.

Table 2: Correlations among variables

\begin{tabular}{|c|c|c|c|c|c|c|c|}
\hline Division & Innovative & Familiarity & Impact & Interaction & $\begin{array}{c}\text { Ease } \\
\text { of use }\end{array}$ & Usefulness & $\begin{array}{c}\text { Use } \\
\text { Intention }\end{array}$ \\
\hline $\begin{array}{c}\text { Personal } \\
\text { Innovativeness }\end{array}$ & $()$. & & & & & & \\
\hline $\begin{array}{c}\text { Personal } \\
\text { Familiarity }\end{array}$ & $.632 * *$ & (.) & & & & & \\
\hline
\end{tabular}




\begin{tabular}{|c|c|c|c|c|c|c|c|}
\hline $\begin{array}{c}\text { Social } \\
\text { influence }\end{array}$ & $.624 * *$ & $.569 * *$ & $()$. & & & & \\
\hline $\begin{array}{c}\text { Social } \\
\text { Interaction }\end{array}$ & $.475 * *$ & $.557 * *$ & $.583 * *$ & $()$. & & & \\
\hline $\begin{array}{c}\text { Perceived } \\
\text { Ease of use }\end{array}$ & $.480 * *$ & $.561 * *$ & $.477 * *$ & $.489 * *$ & $()$. & & \\
\hline $\begin{array}{c}\text { Perceived } \\
\text { Availability }\end{array}$ & $.582 * *$ & $.619 * *$ & $.523 * *$ & $.589 * *$ & $.618 * *$ & $()$. & $.563 * *$ \\
\hline $\begin{array}{c}\text { Continuous } \\
\text { Use Intention }\end{array}$ & $.517 * *$ & $.622 * *$ & $.472 * *$ & $.524 * *$ & $.570 *$ & $()$. \\
\hline
\end{tabular}

Note) Figures in parentheses are the square root of AVE.

$* \mathrm{P}<.05, * * \mathrm{P}<.01$

\subsection{Study model analysis result}

In order to estimate the research model presented in this study, the structural equation modeling technique was applied using AMOS 22.0, and the analysis results are presented in Table 3 and Table 4. The path coefficients shown in the table are all corrected values from measurement errors. First, with regard to the effects of the user characteristics and social characteristic variables on the perceived ease of use as a parameter, all the individual innovativeness as user characteristics variables $(\beta=.249, \mathrm{P}<.01)$ and personal familiarity $(\beta=.330, \mathrm{P}<.01)$, and social influence variables $(\beta=.137, \mathrm{P}<.05)$ and social interactions $(\beta=.197, \mathrm{P}<.01)$ have significant positive effects on perceived ease of use. These results indicate that the perceived ease of use increases with the individual's innovativeness, familiarity, social influence and social interaction increase of use).

Table 3: Effects of antecedent variables on perceived ease of use of use

\begin{tabular}{|l|c|c|c|c|}
\hline \multicolumn{1}{|c|}{ Route } & Coefficient & S.E. & C. R. & P \\
\hline personal innovativeness $\rightarrow$ perceived ease of use & .249 & .056 & $4.238^{* *}$ & .000 \\
\hline personal familiarity $\rightarrow$ perceived ease of use & .330 & .067 & $4.804^{* *}$ & .000 \\
\hline social influence $\rightarrow$ perceived ease of use & .137 & .053 & $2.218^{*}$ & .014 \\
\hline social interaction $\rightarrow$ perceived ease of use & .197 & .052 & $3.446^{* *}$ & .001 \\
\hline
\end{tabular}

$* \mathrm{P}<.05, * * \mathrm{P}<.01$

Next, in Table 4, with regards to the effects of user characteristics, social characteristic variables, and perceived ease of use on perceived availability as another parameter, are the individual characteristics $(\beta=.268, \mathrm{P}<.01)$, and personal familiarity $(\beta=.422, P<.01)$, social characteristic variables $(\beta=.089, P<.05)$, social interactions $(\beta=.198, \mathrm{P}<.01)$, and perceived ease of use $(\beta=.254, \mathrm{P}<.01)$ were found to have a significant positive impact on perceived availability. These results indicate that the perceived availability increases as the personal innovativeness and 
familiarity, social influence and social interaction, and perceived ease of use increase.

Table 4: Effects of antecedent variables on perceived availability

\begin{tabular}{|l|c|c|c|c|}
\hline \multicolumn{1}{|c|}{ Route } & Coefficient & S.E. & C. R. & P \\
\hline $\begin{array}{l}\text { personal innovativeness } \rightarrow \text { perceived } \\
\text { availability }\end{array}$ & .268 & .045 & $5.386^{* *}$ & .000 \\
\hline $\begin{array}{l}\text { personal familiarity } \rightarrow \text { perceived } \\
\text { availability }\end{array}$ & .422 & .052 & $7.546^{* *}$ & .000 \\
\hline social influence $\rightarrow$ perceived availability & .089 & .039 & $1.889^{*}$ & .030 \\
\hline $\begin{array}{l}\text { social interaction perceived } \\
\text { availability }\end{array}$ & .198 & .040 & $4.309^{* *}$ & .000 \\
\hline $\begin{array}{l}\text { perceived ease of use of use } \rightarrow \text { perceived } \\
\text { availability }\end{array}$ & .254 & .042 & $5.828^{* *}$ & .000 \\
\hline
\end{tabular}

$* \mathrm{P}<.05, * * \mathrm{P}<.01$

Finally, as a result of analyzing the effect of the perceived ease of use and availability of the parameters on the sustained use intention as the dependent variable in Table 5 , the perceived ease of use of use $(\beta=.240, \mathrm{P}<.01)$ and perceived availability. $(\beta=.521, \mathrm{P}<.01)$ had a significant positive effect on sustained use intention. This indicates that the higher the perceived ease of use and availability, the higher the intention of continuous use

Table 5: Effects of antecedent variables on continuous use intention

\begin{tabular}{|l|c|c|c|c|}
\hline \multicolumn{1}{|c|}{ Route } & Coefficient & S.E. & C. R. & P \\
\hline perceived ease of use of use $\rightarrow$ continuous intention to use & .240 & .049 & $4.770^{* *}$ & .000 \\
\hline perceived availability $\rightarrow$ continuous intention to use & .521 & .051 & $10.353^{*}$ & .000 \\
\hline
\end{tabular}

$* \mathrm{P}<.05, * * \mathrm{P}<.01$

\section{Discussion and Results}

The purpose of this study is to investigate the structural relationship between factors affecting behavioral change of users using corporate mobile SNS and continuous use intention based on the extended technology acceptance model presented in this study. Based on the research results, authors would like to suggest the implications that corporate mobile SNS can help new business between company and consumer.

First, it was found that the personal innovativeness and familiarity as user characteristics, and the social influence and the social interaction as a user's characteristic factors, have positive effects on between the perceived availability and the perceived ease of use. These findings support the previous studies that 
personal innovativeness, familiarity, social influence and social interaction are factors that can affect perceived availability and ease of use. The more the users who use corporate mobile SNS try and familiarize, the more they voluntarily perceive the ease of use for corporate mobile SNS. In addition, it is found that the information provided by the corporate mobile SNS forms maintains social relationships among users, and shares and recognizes information and knowledge with other users in the corporate mobile SNS.

Second, the perceived availability and ease of use have positive effects on the continuous use intention of corporate mobile SNS users as well as the positive effects of external variables. This supports the extended technology acceptance model proposed in this study that perceived availability and ease of use have a direct impact on behavioral intention. These results increase the acceptance of information technology and efficiency to have a continuous intention to use, create a stable situation in the mobile environment, and provide corporate and product information, content, product purchase and After-Sales Service (A/S) easily through corporate mobile SNS. In other words, it is often recognized as simple information with low burden of producing information with accurate information and high professionalism and can also affect the perceptions of usage of nearby consumers. It also shows that the extended technology acceptance model can be applied not only to the existing online website but also to corporate mobile SNS users.

The results of this study provide important practical implications for communication and relationship formation between corporate mobile SNS and its users. First, as the mobile environment evolves into a user-driven SNS environment, the interface and management system, which are easy to use from a user-centered perspective, are re-defined to improve efficiency. In addition, users who have high utilization of corporate mobile SNS will enhance their relationship formation by enabling them to take on roles and responsibilities as subjects. Through this, it will be possible to effectively develop and integrate a company's business model. Second, it is thought to be necessary to stimulate the user's mind and draw out the efficacy to increase the usefulness by inducing personality and interest with the development of contents that can provide customized service of corporate mobile SNS. In addition, corporate mobile SNS can be a new corporate culture by forming a virtuous cycle of reproduction by reflecting the voluntary opinions and experiences of users as a means of communication (Kim et al., 2019).

\section{References}

Agarwal, R. \& Karahanna, E. (2000). Time flies when you're having fun: Cognitive absorption and beliefs about information technology usage. MIS quarterly, 24(4), 665-694. 
Ajzen, I. (1985). From intentions to actions: a theory of planned behavior, in action control: from cognition to behaviour. J Kuhl and J. Beckmann(eds), Heidelberg, 1139.

Bagozzi, R. P. \& Yi, Y. (1988). On the evaluation of structural equation models. Journal of Academy of Marketing Science, 16(1), 74-94.

Bryant, J., Sanders-Jackson, A. \& Amber S. M. K. (2006). IMing, text messaging and adolescent social networks. Journal of Computer-Mediated Communication, 11(2), 577-592.

Buelingen, F. \& Woerter, M. (2004). Development perspectives, firm strategies and applications in mobile commerce. Journal of business Research, 57(12), 1402-1408.

Cho, Y. (2012). The influence of personal social characteristics on the SNS adoption. Journal of Digital Convergence, 10(2), 121-131.

Choi, K. \& Chun, Y. (2018). A study on the factors affecting continuous use of the mobile office. International Journal on Human and Smart Device Interaction, 5(2), 183.

Choi, M. (2012). Exploratory discussion on the acceptance of the early smart phone users. Journal of Korea Design Forum, 34, 489-498.

Davis, F. D. (1989). Perceived usefulness, perceived ease of use of use, and user acceptance of information technology. MIS Quarterly, 13(3), 319-340.

Davis, F. D. Bogazzi, R. P. and Warshaw, P. R. (1989). User acceptance of customer technology: A comparison of two theoretical models. Management Science, 35(8), 982-1003.

Davis, F. D., Bagozzi, R. P. \& Warshaw, P. R. (1992). Extrinsic and intrinsic motivation to use computers in the workplace1. Journal of Applied Social Psychology, 22(14), 1111-1132.

Davis. F. D. A technology acceptance model for empirically testing new end-user information system: theory and results, Doctoral Dissertation, Sloan School of Management. MIT, 1986.

DeLone, W. H. \& McLean, E. R. (1992). Information system success: the quest for the dependent variable. Information System Research, 3(1), 60-95. 
Delone, W. H. \& McLean, E. R. (2003). The DeLone and McLean model of information systems success: A ten-year update. Journal of Management Information Systems, 19(4), 9-30.

Dishaw, M. T. \& Strong, D. M. (1999). Extending the technology acceptance model with task-technology fit constructs. Information and Management, 36(1), 9-21.

Fishbein, M. \& Ajzen, I. (1975). Belief, attitude, intention and behaviour: an introduction to theory and research, reading. MA: Addison Wesley publishing company.

Fornell, C. \& Larcker, D. F. (1981). Evaluating structural equation models with unobservable variables and measurement error. Journal of Marketing Research, 18(1), 39-50.

Hair, J. F., Anderson, R. E., Tatham, R. L. \& Black, W. C. (2006). Multivariate data analysis. 6th ed., New York: MacMillan Publishing Co.

Han, J. \& Hyun, Y. (2010). An examination of the structural relationships among system quality of tourism knowledge $\&$ information system, perceived ease of use of use, and system-usage satisfaction: application \& extension of the technology acceptance model. Tourism Management Research, 24(4), 175-188.

Internet use survey. (2018). Korea internet and security agency. Ministry of Science and ICT.

Jiang, G., Pen, L. \& Liu, R. (2015). Mobile game adoption in china: the role of TAM and perceived entertainment, cost, similarity and brand trust. International Journal of Hybrid Information Technology, 8(4), 213-232.

Keum, C. \& Kim, B. (2014). Factors affecting the intention to continue using SNS characteristics of a company. The Korea Society of Management information Systems, 906-912.

Kim, D. (2011). An empirical study on user satisfaction and the influencing factors for continuous usage of social network service. Chung, a University Graduate School, 2011.

Kim, J. and Ha, K. (2012). The study of the effects of the enterprise mobile social network service on user satisfaction and the continuous use intention. The Society of Digital Policy \& Management, 10(8), 135-148. 
Kim, J., Kim, M., Hong, R. \& Ko. J. (2019). The effects of User and Characteristics on continous use intention among corporate mobile SNS users. International journal of Smart Business and Technology, 7(2).

Kim, K. (2001). Analysis of AMOS structural equation model Seoul Korea information \& communications.

Kim, S. \& Kim, H. (2018). Smartphone use level of nursing college students the relationship between communication competence social avoidance and distress. International Journal of Mobile Device Engineering, 2(1), 1-6.

Kishore, R., Lee, J. \& McLean, E. R. (2001). The role of personal innovativeness and self-efficacy information technology acceptance: An extension of TAM with notions of risk. ICIS, 23, 6421-6428.

Lim, S. \& Kim, C. (2017). Effects of perceived technology acceptance factors when using a festival social network service on acceptance intention. The Tourism Sciences Society of Korea, 41(6), 11-30.

Mathieson, K. (1991). Predicting user intention: comparing the technology acceptance model with the theory of planned behaviour. Information System Research, 2(2), 173-191.

Noh, M. \& Kim, H. (2007). A study on the influence of mobile characteristics on the mobile service adoption. Journal of Korea Association of Business Education, 48, 125-150.

Nunnally, J. C. (1978). Psychometric theory. 2nd ed., New York: McGraw-Hill.

Rogers, E. M. (2003). Diffusion of innovations. 5th ed, Free Press.

Shen, H., Luo, L. \& Sun, Z. (2015). What affect lower grade learner's perceived usefulness and perceived ease of use of use of mobile digital textbook learning system? An empirical factor analyses investigation in China. International Journal of Multimedia and Ubiquitous Engineering, 10(1), 33-46.

Thong, J. Y., Hong, S. J. \& Tam, K. Y. (2006). The effects of post-adoption beliefs on the expectation-confirmation model for information technology continuance. International Journal of Human-Computer Studies, 64(9), 799-810.

Venkatesh, V. \& Bala, H. (2008). Technology acceptance model 3 \& a research agenda on interventions. Decision Sciences, 39(2), 273-315. 
Venkatesh, V. \& Davis, F. D. (1996). A model of the antecedents of perceived ease of use of use: development and test. Decision Sciences, 27(3), 451-481.

Venkatesh, V. \& Davis, F. D. (2000). A theoretical extension of the technology acceptance model: Four longitudinal field studies. Management Science, 46(2), 186204.

Venkatesh, V. (2000). Determinants of perceived ease of use of use: integrating control, intrinsic motivation, and emotion into the technology acceptance model. Information on Systems Research, 11(4), 342-365.

Venkatesh, V. et al. (2003). User acceptance of information technology: Toward a unified view. MIS Quarterly, 27(3), 425-478.

Verkasalo, H., Lopez-Nikolas, C., Molina-Castila, F. J. \& Bouwman, H. (2010). Analysis of users and non-users of smartphone applications. Telematics and Informatics, 27(3), 242-255.

Xin, G. \& Kim, M. (2018). A study on perceived characteristics of mobile payment system and continuous usage intention. International Journal of Wireless and Mobile Communication for Industrial Systems, 5(2), 1-6. 